\title{
Welcome to the National Wetlands Research Center Library: Not Just Another Library-A Special Library
}

\section{Visiting the Library}

Visitors are welcome to use the NWRC library Monday through Friday from 8:30 a.m. to 3:30 p.m., excluding Federal holidays. Because of security measures, visitors must sign in at the reception desk to receive a badge and directions to the library. The librarian will give a brief orientation to the library and its resources.

\section{Resources}

A knowledgeable, full-time professional librarian is available to assist with locating library materials and using online and print resources. Research databases and collections provide access to wellorganized information. The library's collections include the following subject specialties: forested wetland ecology, fire science, spatial analysis, remote sensing, modeling, statistical analysis, marsh and coastal prairie management and restoration, plant communities, habitats, aquatic ecosystems, climate change, wetland loss, hurricanes, nutrient dynamics, and limnology.

Library holdings include books, print periodicals, full-text electronic journals, VHS tapes, DVDs, CDs, audio tapes, and microforms. Topical collections include:

-Reprints (subject specific publications and those authored by NWRC scientists)

- Scientific and technical reports (for example, U.S. Fish and Wildlife Service reports, National Biological Service reports, USGS Biological Resources Discipline reports)

— Statistics reference materials

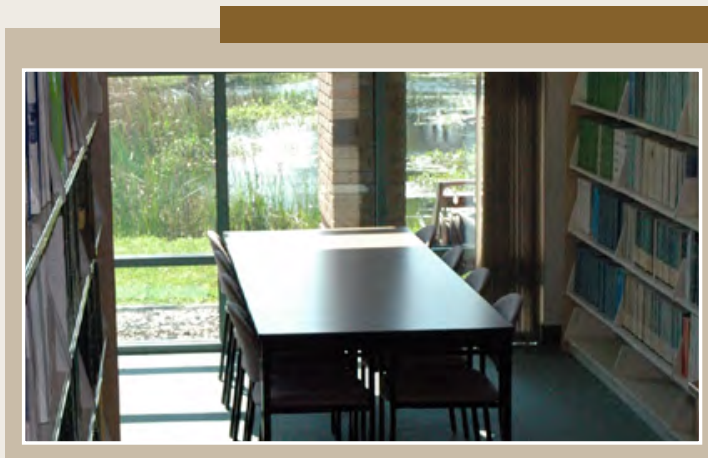

A USGS Library Dedicated to Wetland Science
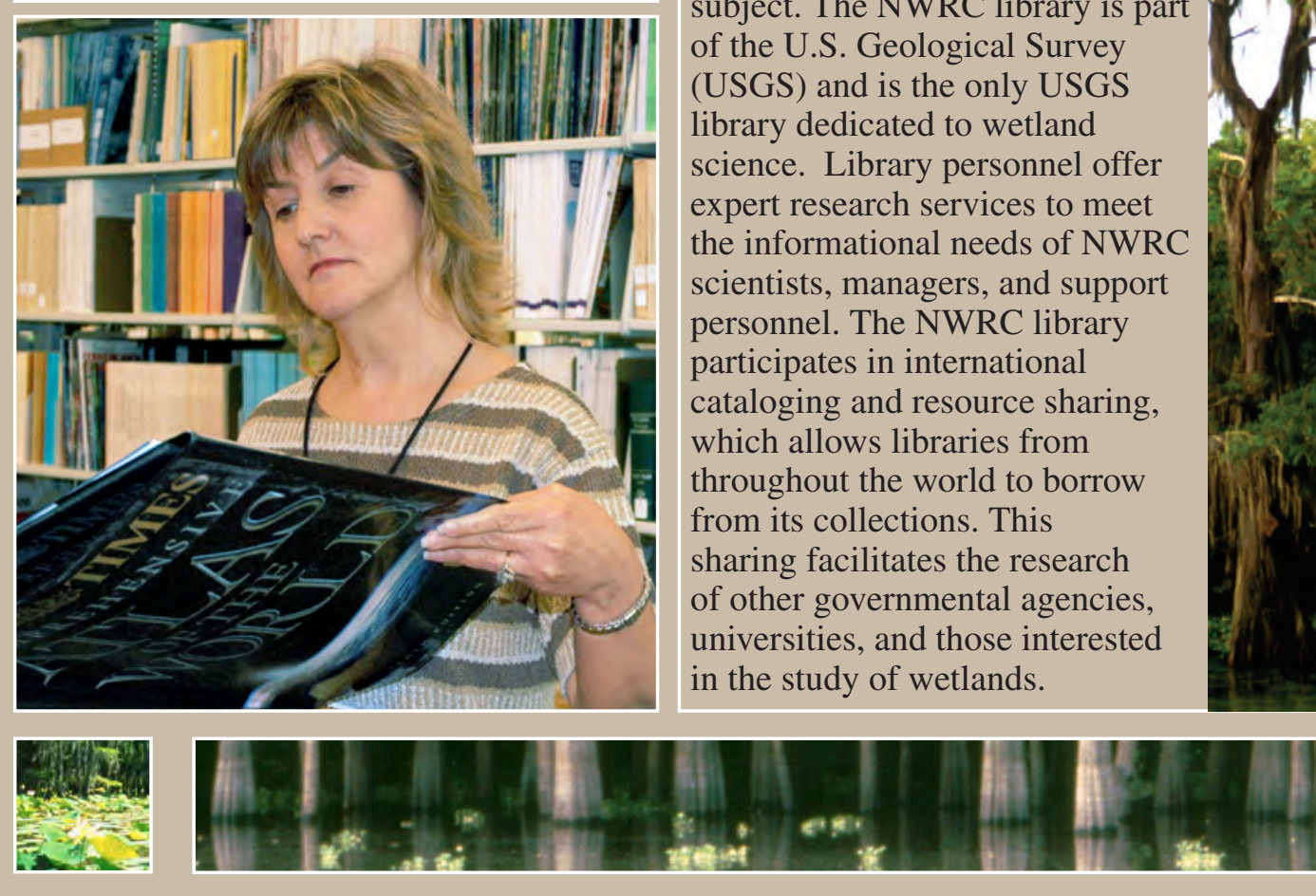

-Cartographic collection

- Specialized directories of Web resources

-K-12 student and educator collection

—Computer software manuals

\section{Special Collections}

The NWRC library houses several unique collections:

\section{About the Library}

Libraries are grouped into four major types: public, school, academic, and special. The National Wetlands Research Center (NWRC) library is classified as a special library because it is sponsored by the Federal government, and the collections focus on a specific subject. The NWRC library is part of the U.S. Geological Survey (USGS) and is the only USGS library dedicated to wetland science. Library personnel offer expert research services to meet the informational needs of NWRC scientists, managers, and support personnel. The NWRC library participates in international cataloging and resource sharing, which allows libraries from throughout the world to borrow from its collections. This sharing facilitates the research of other governmental agencies, universities, and those interested in the study of wetlands. 


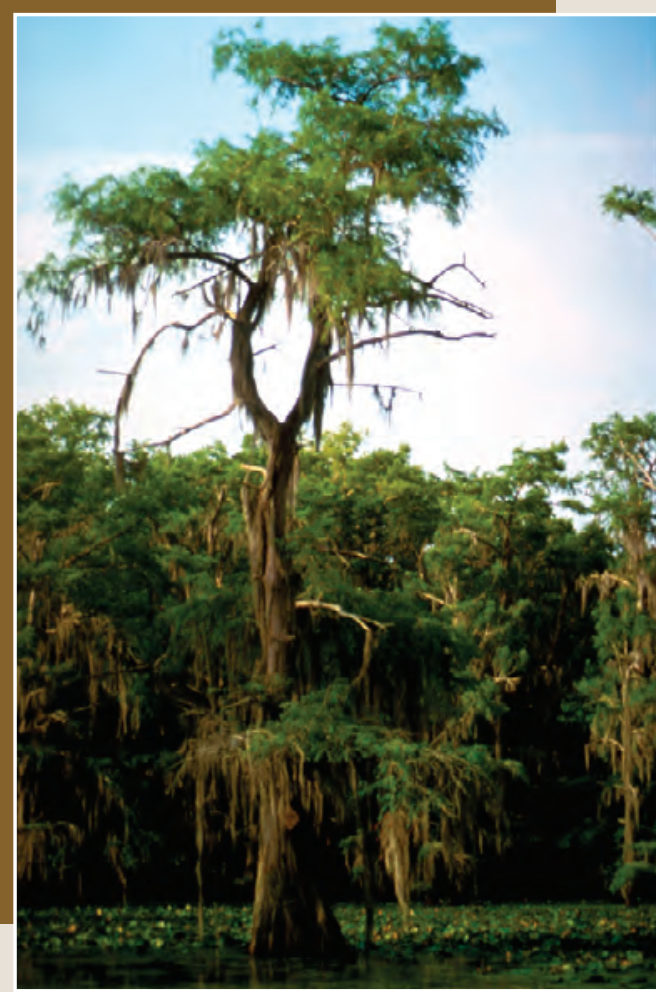

covering historical wildlife refuges located in Louisiana and Mississippi. This collection is noncirculating.

-The National Wetlands Research Center Archives include information on and about NWRC since its foundation in 1975 as part of the U.S. Fish and Wildlife Service, Office of Biological Services. This is a noncirculating collection and is available for in-library use only.
Computers have software applications for word processing and creating spreadsheets, databases, and presentation materials, and they include access to the Internet, e-mail, and library catalog. To use computers or electronic resources, including databases and journals, please see the librarian. There are no fees for printing.

\section{Borrowing}

Visitors may use materials in the library and make a limited number of photocopies. The library does not charge for copies. Persons requiring off-site use of materials owned by the library may request items through ILL services offered at their local public, school, university, or corporate library. Interlibrary loan departments may request items through OCLC, by mail, fax machine, telephone, or e-mail. The NWRC library's OCLC symbol is FZU.

Upper-level student interns may receive restricted borrowing privileges with approval of their NWRC sponsor and the librarian. Students are expected to seek ILL services from their home university.

At the discretion of the NWRC librarian, agency and other partners may borrow library material from circulating collections. The NWRC library offers limited interlibrary loan (ILL) services to partners.

\section{Reference and Research}

The library provides limited reference assistance to visitors if the question concerns a topic within the scope of the NWRC library. The librarian is unable to offer research services or answer questions with time-sensitive needs, such as homework, but may be able to assist with longer-term assignments such as science fair projects. Students are encouraged to contact their local school or public librarian for help with locating appropriate resources.

We encourage student interns to seek reference and research services from their home university.

Reference and research services are extended to partners; however, staff research requirements receive priority.

\section{For more information contact}

Linda Broussard

U.S. Geological Survey

National Wetlands Research Center 700 Cajundome Blvd.

Lafayette, LA 70506-3152

Phone 337-266-8692

Fax 337-266-8841

nwrclibrary@usgs.gov

http://www.nwrc.usgs.gov/library.htm

\section{Access}

The NWRC library offers 24-hour access to the online catalog and selected Web resources at $h t t p: / / w w w$. nwrc.usgs.gov/library.htm

Users can search library holdings via the online catalog or by visiting the library. Please call ahead to make certain that the librarian will be available to meet with you and provide assistance. Visitors may browse the collections, which are organized according to the Library of Congress classification system, or search the periodical holdings, which are arranged alphabetically by title.

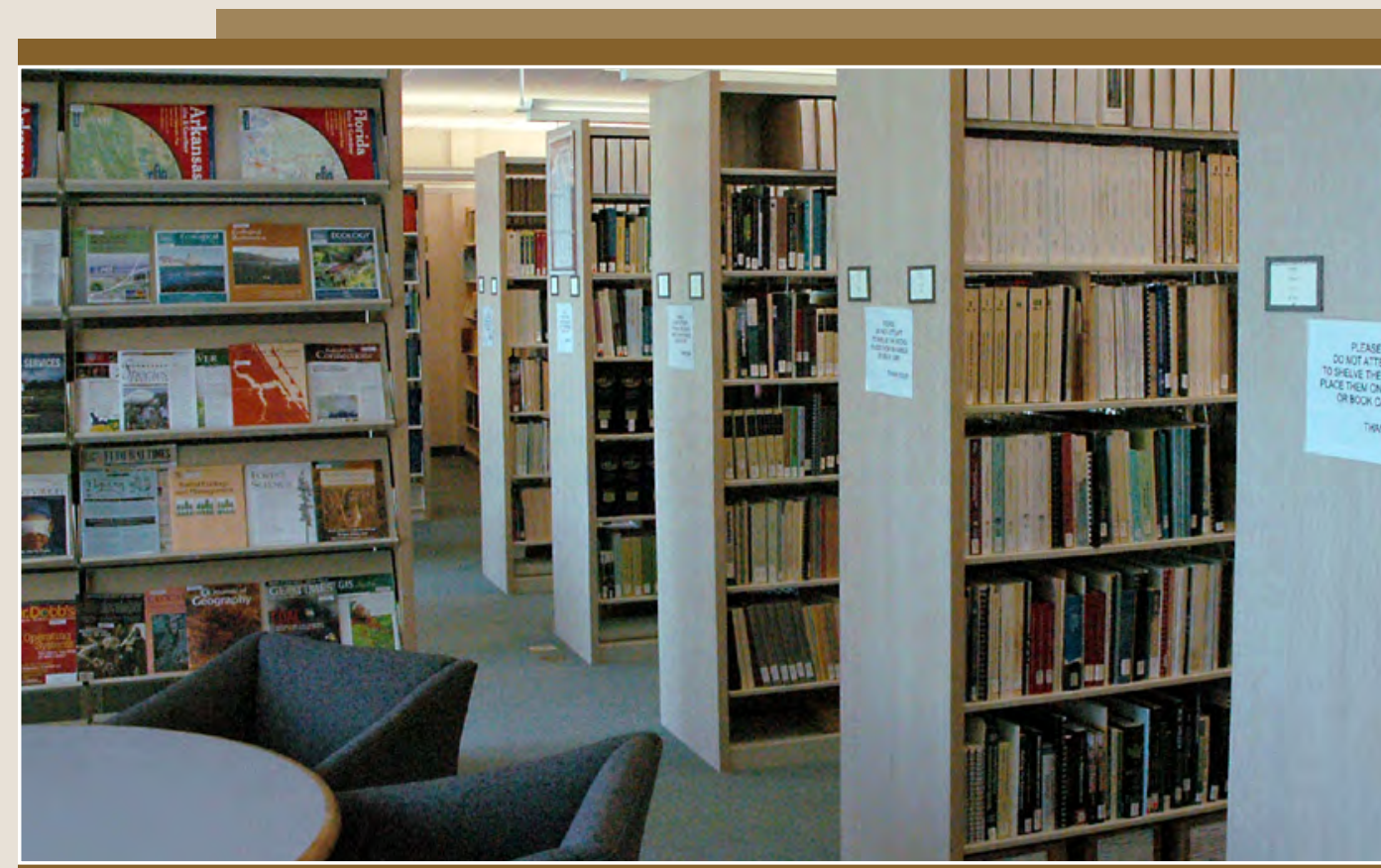

